Article

\title{
Chemical Properties of Soil and Cassava Yield as a Function of Weed Management by Cover Crops in the Amazon Ecosystem
}

\author{
Daniel Oscar Soares ${ }^{1}$, Karla Gabrielle Pinto ${ }^{1} \mathbb{D}$, Prasanta Chitta Bhowmik ${ }^{2}$ and Sônia Maria Albertino ${ }^{1, *}$ \\ 1 Programa de Pós-graduação em Agronomia Tropical, Universidade Federal do Amazonas, \\ Manaus 69067-005, Brazil; daniel_oscar@live.com (D.O.S.); karladutraa@gmail.com (K.G.P.) \\ 2 Stockbridge School of Agriculture, University of Massachusetts, Amherst, MA 01003, USA; \\ pbhowmik@umass.edu \\ * Correspondence: sonia.albertino@gmail.com
}

Citation: Soares, D.O.; Pinto, K.G.; Bhowmik, P.C.; Albertino, S.M.

Chemical Properties of Soil and

Cassava Yield as a Function of Weed Management by Cover Crops in the Amazon Ecosystem. Sustainability 2022, 14, 1886. https://doi.org/ $10.3390 /$ su14031886

Academic Editors: Othmane Merah Purushothaman Chirakkuzhyil Abhilash, Magdi T. Abdelhamid, Hailin Zhang and Bachar Zebib

Received: 16 December 2021

Accepted: 22 January 2022

Published: 7 February 2022

Publisher's Note: MDPI stays neutral with regard to jurisdictional claims in published maps and institutional affiliations.

Copyright: (C) 2022 by the authors. Licensee MDPI, Basel, Switzerland. This article is an open access article distributed under the terms and conditions of the Creative Commons Attribution (CC BY) license (https:// creativecommons.org/licenses/by/ $4.0 /)$.

\begin{abstract}
Cassava (Manihot esculenta) yields are severely affected by the interference of weed plants. Using cover crops for weed control appears as a sustainable alternative practice because it maintains the soil covered and reduces the need for herbicides. The aim of this study was to assess cassava crop yields and the soil chemical properties as a function of use of cover crops for weed management. Treatments were three cover crops (Brachiaria ruziziensis, Canavalia ensiformis, and Mucuna pruriens), chemical control, mechanical control, and treatment with no weed control. Cover crops reduced the diversity of species and the quantity of individuals of the weed community in cassava cultivation. The treatments with chemical and physical weed control achieved higher yields. The cover crops B. ruziziensis and C. ensiformis increased cassava yields by $30 \%$ and $14 \%$, respectively, when compared with the treatment with no control. The cover crops increased the $\mathrm{pH}, \mathrm{MO}, \mathrm{K}, \mathrm{Ca}$, and $\mathrm{Mg}$ values when compared with the treatments with chemical and mechanical weed control. Brachiaria ruziziensis and C. ensiformis are recommended as a cover plants in cassava production systems in the Amazon region. The use of cover crops associated with cassava is a sustainable management option because, in addition to the suppressive effect on weeds, cover crops improve the chemical properties of soil, which may contribute to increasing cassava production in the long term.
\end{abstract}

Keywords: Brachiaria ruziziensis (syn. Urochloa ruziziensis); Canavalia ensiformis; Manihot esculenta; Mucuna pruriens; soil fertility; weed control

\section{Introduction}

Studies addressing sustainable alternatives for vegetable production are important, especially in the Amazon region, where preservation of the ecosystem is essential to maintain biodiversity. Cassava is a plant native to the Amazon region which belongs to the family Euphorbiaceae and the genus Manihot [1].

In the state of Amazonas, cassava is mainly cultivated by small farmers, and most of the production is destined to subsistence and animal feeding. Due to the high level of rusticity of this culture and low technology required for cultivation, many cassava growers underestimate the need for weed control. However, when not managed properly, weed plants constitute a major limiting factor for cassava production and contribute to the low crop yields found in the state of Amazonas $\left(9.83 \mathrm{t} \mathrm{ha}^{-1}\right)$, in contrast with other Brazilian states, including those in the North region, of about $20 \mathrm{tha}^{-1}$ [2].

With respect to weed management by local producers, when not neglected, control is achieved by manual weeding, using hoes, a practice that is not totally viable due to the shortage of labor in addition to the weather conditions, such as high humidity and temperatures, which make it difficult to perform this practice [3]. For this reason, producers have been increasingly interested in using herbicides due to the small number of workers required, in addition to the high control efficacy and low production costs. The increasing 
use of herbicides in Amazonia crops deserves attention, considering that the inadequate use of these products may cause irreversible environmental damages [4].

The integration of grass and legume as cover crops into the cropping system can bring numerous benefits to the soil, such as an increased availability of nutrients, soil organic carbon, total nitrogen, and reduced nitrate leaching and soil loss [5-7]. Improvements in soil chemical properties may contribute to a greater development of shoots and faster canopy closure and, consequently, more shading on weeds, reducing the interference of these plants with cassava [8].

However, recommendations of cover crops for a given culture depend on practical studies and fine adjustments that consider the characteristics of the crop, the cover crops used, the composition of the weeding community, climate, and the local reality. Studies investigating the effects of cover crops on productivity and on the chemical properties of soil in cultivated crops in Amazonia are still incipient.

Thus, the objective of this research was to examine the effects of cover crops and chemical and mechanical controls on cassava yields and on the chemical properties of soil, aiming at the incorporation of good practices in cassava cropping systems, promoting sustainability and food security.

\section{Materials and Methods}

Two experiments were conducted at the Experimental Farm of the Federal University of Amazonas (Latitude: $02^{\circ} 37^{\prime} 17.100^{\prime \prime}$ and $02^{\circ} 39^{\prime} 41.400^{\prime \prime}$ S; Longitude: $60^{\circ} 03^{\prime} 29.100^{\prime \prime}$ and $\left.60^{\circ} 07^{\prime} 57.500^{\prime \prime} \mathrm{W}\right)$, state of Amazonas, Brazil, in two growing seasons, 2018/2019 and 2019/2020. The climate is "Am" type, according to Köppen classification [9,10], humid tropical, with air relative humidity around $89 \%$, annual rainfall around $2000 \mathrm{~mm}$.

The experimental area was prepared with light harrowing and fertilization as recommended for cassava cultivation in the region [11]. The cultivar chosen was Manteiga, considered sweet cassava, which has a 12-month cycle, average yield of $15 \mathrm{tha}^{-1}$ and hydrocyanic acid concentration below $50 \mathrm{mg} \mathrm{kg}^{-1}$ [12].

Propagation was made with stem cuttings of 10 to $15 \mathrm{~cm}$ in length from adult cassava plants, with 3 to 6 bud eyes, called manivas in the region. The stem cuttings (manivas) were deposited horizontally in 10-cm deep bed furrows and covered with earth. Spacing was $1 \mathrm{~m}$ between rows and between plants, totaling 10,000 plants ha $^{-1}$.

The experiment was conducted in a randomized block design with six treatments and four replicates. Each plot was made up of five planting rows, with six plants per row, totaling thirty plants per plot. The net area of each plot comprised the central region of the plot, using three central lines and disregarding the border plants, totaling 12 useful plants for assessment. Treatments were three cover crop species (Brachiaria ruziziensis, Canavalia ensiformis, and Mucuna pruriens); chemical control with herbicide; mechanical control; and treatment with no weed control. The chemical and mechanical weed controls were conducted 3 months after planting, with 2-month intervals, totaling 5 operations for both.

Surveys on the floristic and phytosociological composition of the weed plants were carried out prior to implementation of the experiment and at its completion, using quadrat samplers with an area of $0.12 \mathrm{~m}^{2}$, which were placed at random twice on each plot, totaling $0.96 \mathrm{~m}^{2}$ of sampled area per treatment and $5.76 \mathrm{~m}^{2}$ of total sampled area for each year. The calculated phytosociological parameters were relative frequency, relative density, relative abundance and the importance value index (IVI), as proposed by Mueller-Dombois and Ellenberg [13].

As the initial growth stage of cassava favors the emergence and interference of weeds $[8,14]$, the cover crops were planted three months after planting cassava to minimize the risks of interference. Planting density was $9 \mathrm{~kg} \mathrm{ha}^{-1}$ for B. ruziziensis, and $80 \mathrm{~kg} \mathrm{ha}^{-1}$ for $C$. ensiformis and $M$. pruriens. The grass plants were planted in furrows between the cassava planting lines, while legumes were planted in 3-6 cm deep holes $40 \mathrm{~cm}$ apart. 
All cover plants were sown at a distance of $30 \mathrm{~cm}$ from the cassava rows to reduce risks of interference.

In the chemical control treatment, glyphosate $\left(480 \mathrm{~g}\right.$ a.i. $\left.\mathrm{ha}^{-1}\right)$ was directedly sprayed at post-emergence, using an automated back sprayer, pump pressure of 40 to $60 \mathrm{lb} \mathrm{pol}^{-1}$, nozzle 80.04, with a dosage of $3.5 \mathrm{~L} \mathrm{ha}^{-1}$. The mechanical control consisted of hoeing for weed suppression.

At 360 days after planting, the period that corresponds to the completion of the cassava growth cycle, yields were assessed by weighing the roots of the plants grown in the net area of each treatment. The roots were cleaned with water, carefully peeled and immediately weighed to obtain fresh weight and, afterwards, were dried in forced-air circulation oven at $65{ }^{\circ} \mathrm{C}$ for $72 \mathrm{~h}$, or to reach constant weight. Production values were converted to yield, expressed in tons ha ${ }^{-1}$, using the formula: yield $\left(\mathrm{t} \mathrm{ha}^{-1}\right)=$ weight $(\mathrm{kg})$ of root of 12 useful plants $\times 10,000$ plants $\times$ twelve $^{-1}$.

At harvest, the plant mean height, stem diameter, shoot dry weight, and root counts per plant were determined. The mean height of the plants, determined at harvest, consisted of the distance between the tip of the stem base to the tip of the highest shoot. The stem diameter was determined by measuring the basal diameter at $5 \mathrm{~cm}$ above the ground using a caliper. The usable plants from each plot were cut at the ground level, and the vegetable tissues were chopped and placed in a forced-air circulation oven at $65^{\circ} \mathrm{C}$ for $72 \mathrm{~h}$, or until reaching constant weight, and their sum was used to estimate the shoot dry weight and the values were transformed into tons ha ${ }^{-1}$

The soil samples were collected using a hand auger from the $0-20 \mathrm{~cm}$ depth at the end of each experiment. The concentrations of phosphorus (P), potassium (K), calcium (Ca), magnesium $(\mathrm{Mg})$, zinc $(\mathrm{Zn}), \mathrm{pH}$, organic matter $(\mathrm{MO})$, and potential acidity $(\mathrm{H}+\mathrm{Al})$, were determined according to the methodology proposed by Raij and Quaggio [15].

The resulting data were subjected to analysis of variance, and the F-test was applied, and the means were compared by the Tukey test at $5 \%$ probability level. Statistical analyses were carried out using the statistical software program RStudio, version 1.3.1093 [16].

\section{Results and Discussion}

\subsection{Phytosociological Parameters of Weeds}

In the first phytosociological survey, 962 individuals were recorded, distributed into 16 species, belonging to nine botanical families. The Poaceae family was the most representative, with five species, followed by Cyperaceae, Fabaceae, and Verbenaceae families, each one with two species (Table 1). The importance of the Poaceae family for crops grown in the country has already been observed in other studies involving weed plants in crops in the Amazon region, e.g., Fontes et al. [17], Da Gama et al. [18], Damasceno [19], De Almeida et al. [20], Dos Santos [21], Miléo et al. [22], and Albertino et al. [23].

Concerning classes, there was a balance between the number of monocotyledon and dicotyledon species, each one with eight species. However, there was a predominance of monocotyledons in the first year $(83.05 \%)$, mainly due to the high number of individuals of the Axonopus affinis and Paspalum multicaule species, which together represented more than $70 \%$ of the individuals found.

Concerning species, the highest IVI was achieved by A. affinis (84.81), mainly due to the total number of individuals and high relative density. This is a perennial, stoloniferous, creeping, fast-growing grass species, tolerant to cutting and trampling, which is considered difficult to control due to the high rooting capacity of its stolons [24].

This species was also identified by Miléo et al. [22] in a cassava cultivated field in the state of Amazonas, where a high IVI for A. affinis was found. Likewise, the study conducted by Da Gama et al. [18] showed that a species of the genus Axonopus achieved the highest IVI in guarana culture.

At the end of the first year of the experiment, changes in the floristic composition of the weed plants were observed, with the emergence of new species, while other species disappeared (Table 2). 
Table 1. Phytosociological parameters of weed plants prior to installation of the experiment in 2018.

Manaus, AM.

\begin{tabular}{|c|c|c|c|c|c|c|c|}
\hline Class $^{1}$ & Family & Scientific Names & TNI & RFr & RDe & $\mathbf{R A b}$ & IVI \\
\hline M & Poaceae & Axonopus affinis & 414 & 23.97 & 43.04 & 17.80 & 84.81 \\
\hline M & Poaceae & Paspalum multicaule & 293 & 20.55 & 30.46 & 14.70 & 65.70 \\
\hline $\mathrm{D}$ & Fabaceae & Mimosa pudica & 129 & 23.97 & 13.41 & 5.55 & 42.93 \\
\hline M & Cyperaceae & Cyperus rotundus & 31 & 1.37 & 3.22 & 23.33 & 27.92 \\
\hline M & Cyperaceae & Cyperus diffusus & 27 & 2.74 & 2.81 & 10.16 & 15.70 \\
\hline M & Commelinaceae & Commelina erecta & 17 & 2.74 & 1.77 & 6.40 & 10.90 \\
\hline M & Poaceae & Paspalum virgatum & 12 & 1.37 & 1.25 & 9.03 & 11.65 \\
\hline $\mathrm{D}$ & Fabaceae & Pueraria phaseoloides & 12 & 8.22 & 1.25 & 1.50 & 10.97 \\
\hline $\mathrm{D}$ & Rubiaceae & Spermacoce verticillata & 16 & 4.11 & 1.66 & 4.01 & 9.79 \\
\hline M & Poaceae & Eleusine indica & 4 & 1.37 & 0.42 & 3.01 & 4.80 \\
\hline $\mathrm{D}$ & Amaranthaceae & Alternanthera tenella & 2 & 2.74 & 0.21 & 0.75 & 3.70 \\
\hline M & Poaceae & Homolepis aturensis & 1 & 1.37 & 0.10 & 0.75 & 2.23 \\
\hline $\mathrm{D}$ & Solanaceae & Solanum stramoniifolium. & 1 & 1.37 & 0.10 & 0.75 & 2.23 \\
\hline $\mathrm{D}$ & Euphorbiaceae & Croton glandulosus & 1 & 1.37 & 0.10 & 0.75 & 2.23 \\
\hline $\mathrm{D}$ & Verbenaceae & Stachytarpheta cayennensis & 1 & 1.37 & 0.10 & 0.75 & 2.23 \\
\hline \multirow[t]{2}{*}{$\mathrm{D}$} & Verbenaceae & Lantana camara & 1 & 1.37 & 0.10 & 0.75 & 2.23 \\
\hline & & Total & 962 & 100.00 & 100.00 & 100.00 & 300.00 \\
\hline
\end{tabular}

${ }^{1} \mathrm{M}=$ monocotyledons; $\mathrm{D}=$ dicotyledons; $\mathrm{TNI}=$ total number of individuals; $\mathrm{RFr}=$ relative frequency; $\mathrm{RDe}=$ relative density; $\mathrm{RAb}=$ relative abundance; $\mathrm{IVI}=$ importance value index.

Weed plants were not found in the herbicide-treated area, differently from the treatment using mechanical control, where the presence of some weed species was recorded, although there was a reduction of $80 \%$ in the total number of individuals compared with the treatment with no weed control.

Among the cover crops, B. ruziziensis was the one that exhibited the smallest number of weed species (4). This cover crop also reduced the total number of individuals by nearly $75 \%$ when compared to the treatment with no control, mainly due to its rapid establishment and because it grows in clumps, which increases its competitive ability. These results are in agreement with those found by Soares et al. [3] and Da Gama et al. [18], where this species exhibited excellent soil coverage and good weed suppression, with potential for use as cover crops in the Amazon region.

Regarding $C$. ensiformis, this cover crop exhibited the greatest number of weed species (10), probably due to the upright, determined, and initially slow growth of this legume, which may have favored the emergence of new weed species [25]. Yet, it provided a 29\% reduction in the total number of weeds, an intermediate percentage between that found for B. ruziziensis and $M$. pruriens.

Mucuna pruriens was the cover crop with the lowest reduction of the total number of individuals (12\%) compared with the treatment with no weed control, which may be due to the climbing growth habit of this species, allowing more space available in the soil for weed germination and development [3].

In the phytosociological survey conducted in the total area, prior to the installation of the second experiment, 924 individuals distributed in 19 species were found, 9 monocotyledons and 10 dicotyledons. The Poaceae family was the most abundant, with five species, followed by the Cyperaceae and Euphorbiaceae families, each one with three species (Table 3). 
Table 2. Phytosociological parameters of weed plants in a cassava crop grown with different weed management systems in 2019. Manaus, AM.

\begin{tabular}{|c|c|c|c|c|c|c|}
\hline Treatments & Scientific Names & TNI $^{1}$ & RFr & RDe & $\mathbf{R A b}$ & IVI \\
\hline \multirow[t]{2}{*}{ Chemical control } & No weed found & 0 & 0 & 0 & 0 & 0 \\
\hline & Total & 0 & 0 & 0 & 0 & 0 \\
\hline \multirow{5}{*}{ Mechanical control } & Mimosa pudica & 10 & 25.00 & 34.48 & 34.48 & 93.97 \\
\hline & Croton glandulosus & 7 & 18.75 & 24.14 & 24.14 & 67.03 \\
\hline & Alternanthera tenella & 6 & 25.00 & 20.69 & 20.69 & 66.38 \\
\hline & Axonopus affinis & 4 & 18.75 & 13.79 & 13.79 & 46.34 \\
\hline & Acalypha arvensis & 2 & 12.50 & 6.90 & 6.90 & 26.29 \\
\hline \multicolumn{2}{|c|}{ Total } & 29 & 100.00 & 100.00 & 100.00 & 300.00 \\
\hline \multirow{6}{*}{ No weed control } & Paspalum multicaule & 93 & 17.65 & 66.43 & 68.74 & 152.81 \\
\hline & Croton glandulosus & 20 & 29.41 & 14.29 & 8.87 & 52.57 \\
\hline & Mimosa pudica & 18 & 29.41 & 12.86 & 7.98 & 50.25 \\
\hline & Acalypha arvensis & 5 & 11.76 & 3.57 & 5.54 & 20.88 \\
\hline & Cyperus distants & 3 & 5.88 & 2.14 & 6.65 & 14.68 \\
\hline & Euphorbia heterophylla & 1 & 5.88 & 0.71 & 2.22 & 8.81 \\
\hline \multicolumn{2}{|c|}{ Total } & 140 & 100.00 & 100.00 & 100.00 & 300.00 \\
\hline \multirow{4}{*}{ B. ruziziensis } & Croton glandulosus & 15 & 33.33 & 45.45 & 40.00 & 118.79 \\
\hline & Mimosa pudica & 12 & 33.33 & 36.36 & 32.00 & 101.70 \\
\hline & Axonopus affinis & 5 & 22.22 & 15.15 & 20.00 & 57.37 \\
\hline & Homolepis aturensis & 1 & 11.11 & 3.03 & 8.00 & 22.14 \\
\hline & & 33 & 100.00 & 100.00 & 100.00 & 300.00 \\
\hline \multirow{9}{*}{ M. pruriens } & Paspalum multicaule & 32 & 5.00 & 26.23 & 45.55 & 76.78 \\
\hline & Mimosa pudica & 36 & 30.00 & 29.51 & 8.54 & 68.05 \\
\hline & Homolepis aturensis & 17 & 10.00 & 13.93 & 12.10 & 36.03 \\
\hline & Croton glandulosus & 13 & 20.00 & 10.66 & 4.63 & 35.28 \\
\hline & Axonopus affinis & 8 & 5.00 & 6.56 & 11.39 & 22.95 \\
\hline & Rhynchospora nervosa & 7 & 5.00 & 5.74 & 9.96 & 20.70 \\
\hline & Acalypha arvensis & 4 & 10.00 & 3.28 & 2.85 & 16.13 \\
\hline & Cyperus distants & 3 & 10.00 & 2.46 & 2.14 & 14.59 \\
\hline & Pueraria phaseoloides & 2 & 5.00 & 1.64 & 2.85 & 9.49 \\
\hline \multicolumn{2}{|c|}{ Total } & 122 & 100.00 & 100.00 & 100.00 & 300.00 \\
\hline \multirow{11}{*}{ C. ensiformis } & Homolepis aturensis & 30 & 6.67 & 30.30 & 36.81 & 73.78 \\
\hline & Cyperus distants & 15 & 6.67 & 15.15 & 18.40 & 40.22 \\
\hline & Croton glandulosus & 9 & 20.00 & 9.09 & 3.68 & 32.77 \\
\hline & Paspalum multicaule & 11 & 6.67 & 11.11 & 13.50 & 31.27 \\
\hline & Mimosa pudica & 9 & 13.33 & 9.09 & 5.52 & 27.95 \\
\hline & Axonopus affinis & 8 & 13.33 & 8.08 & 4.91 & 26.32 \\
\hline & Rhynchospora nervosa & 8 & 6.67 & 8.08 & 9.82 & 24.56 \\
\hline & Alternanthera tenella & 6 & 13.33 & 6.06 & 3.68 & 23.07 \\
\hline & Spermacoce verticillata & 2 & 6.67 & 2.02 & 2.45 & 11.14 \\
\hline & Acalypha arvensis & 1 & 6.67 & 1.01 & 1.23 & 8.90 \\
\hline & & 99 & 100.00 & 100.00 & 100.00 & 300.00 \\
\hline
\end{tabular}

${ }^{1} \mathrm{TNI}$ = total number of individuals; $\mathrm{RFr}=$ relative frequency; $\mathrm{RDe}=$ relative density; $\mathrm{RAb}$ = relative abundance IVI = importance value index . 
Table 3. Phytosociological parameters of weed species before installation of the experiment in 2019.

Manaus, AM.

\begin{tabular}{|c|c|c|c|c|c|c|c|}
\hline Class $^{1}$ & Family & Scientific Names & TNI & RFr & RDe & $\mathbf{R A b}$ & IVI \\
\hline $\mathrm{D}$ & Fabaceae & Mimosa pudica & 404 & 17.67 & 43.72 & 19.49 & 80.89 \\
\hline M & Poaceae & Axonopus affinis & 130 & 8.84 & 14.07 & 12.54 & 35.45 \\
\hline $\mathrm{D}$ & Verbenaceae & Stachytarpheta cayennensis & 102 & 14.42 & 11.04 & 6.03 & 31.49 \\
\hline M & Poaceae & Paspalum multicaule & 73 & 4.65 & 7.90 & 13.38 & 25.93 \\
\hline M & Cyperaceae & Rhynchospora nervosa & 35 & 10.70 & 3.79 & 2.79 & 17.28 \\
\hline $\mathrm{D}$ & Euphorbiaceae & Croton lobatus & 32 & 7.44 & 3.46 & 3.67 & 14.57 \\
\hline $\mathrm{D}$ & Rubiaceae & Spermacoce verticillata & 32 & 3.72 & 3.46 & 7.33 & 14.52 \\
\hline $\mathrm{D}$ & Fabaceae & Pueraria phaseoloides & 20 & 8.37 & 2.16 & 2.04 & 12.57 \\
\hline $\mathrm{D}$ & Euphorbiaceae & Acalypha arvensis & 24 & 3.72 & 2.60 & 5.50 & 11.82 \\
\hline M & Poaceae & Homolepis aturensis & 21 & 4.65 & 2.27 & 3.85 & 10.77 \\
\hline M & Poaceae & Eleusine indica & 15 & 2.79 & 1.62 & 4.58 & 9.00 \\
\hline M & Poaceae & Paspalum virgatum & 15 & 2.79 & 1.62 & 4.58 & 9.00 \\
\hline M & Cyperaceae & Cyperus rotundus & 5 & 0.93 & 0.54 & 4.58 & 6.05 \\
\hline M & Cyperaceae & Cyperus diffusus & 4 & 0.93 & 0.43 & 3.67 & 5.03 \\
\hline M & Commelinaceae & Commelina erecta & 4 & 1.86 & 0.43 & 1.83 & 4.13 \\
\hline $\mathrm{D}$ & Amaranthaceae & Alternanthera tenella & 3 & 1.86 & 0.32 & 1.37 & 3.56 \\
\hline $\mathrm{D}$ & Euphorbiaceae & Croton glandulosus & 2 & 1.86 & 0.22 & 0.92 & 2.99 \\
\hline $\mathrm{D}$ & Violaceae & Hybanthus calceolaria & 2 & 1.86 & 0.22 & 0.92 & 2.99 \\
\hline \multirow[t]{2}{*}{$\mathrm{D}$} & Verbenaceae & Lantana camara & 1 & 0.93 & 0.11 & 0.92 & 1.96 \\
\hline & & Total & 924 & 100.000 & 100.000 & 100.000 & 300.000 \\
\hline
\end{tabular}

Differently from what was found in the first year, there was predominance of dicotyledonous individuals in the second year $(67.32 \%)$, mainly due to the great number of M. pudica individuals, which corresponded to approximately $44 \%$ of the individuals identified in this survey.

Despite the changes in the floristic composition of the weeding community, most of the individuals identified before the installation of the second experiment had already been recorded in the weed survey conducted in the first year. Among the five weed species with the highest IVI in the surveys carried out before installation of the experiments in both years were M. pudica, A. affinis, and P. multicaule.

Mimosa pudica stands out from the other species for being the one with the highest IVI in the second year (80.89). It is a perennial, herbaceous, or slightly woody, thorny weed plant, with sensitive leaves, prostrate growth habit and propagation by seeds [26]. It is considered a very rustic plant, with good development in soils with low nutrient availability, producing seeds that are capable of germinating under water and saline stress conditions, being indicated for recovery of degraded areas [27].

The mechanical control of this species is difficult because of the thorns and woody roots and also because of the high seed production. Many seeds can remain in the seedbanks in the soil and cause long periods of reinfestation. Because it is very common in the Amazon region, M. pudica was already found in diverse studies on weed plants in regional cultivated areas, such as those by Dos Santos [21], Alves Albuquerque et al. [28], and Albertino et al. [23], and has already been considered one of the most important weeds in cassava crop fields [22] and cowpea cultivation [29].

Similar to the first year of the experiment, there were changes in the floristic composition of the weeding community at the end of the second year. However, M. pudica was the most important species, both in the first survey and in the final one, considering the highest values found for all parameters assessed (Table 4). 
Table 4. Phytosociological parameters of weed plants in a cassava crop grown with different weed management systems in 2020. Manaus, AM.

\begin{tabular}{|c|c|c|c|c|c|c|}
\hline Treatments & Scientific Names & $\mathrm{TNI}^{1}$ & RFr & RDe & Rab & IVI \\
\hline \multirow[t]{2}{*}{ Chemical control } & No weed found & 0 & 0 & 0 & 0 & 0 \\
\hline & Total & 0 & 0 & 0 & 0 & 0 \\
\hline \multirow{3}{*}{ Mechanical control } & Mimosa pudica & 9 & 44.44 & 47.37 & 36.00 & 127.81 \\
\hline & Croton lobatus & 6 & 33.33 & 31.58 & 32.00 & 96.91 \\
\hline & Axonopus affinis & 4 & 22.22 & 21.05 & 32.00 & 75.27 \\
\hline & Total & 19 & 100.00 & 100.00 & 100.00 & 300.00 \\
\hline \multirow{7}{*}{ No weed control } & Mimosa pudica & 123 & 25.00 & 54.42 & 36.57 & 116.00 \\
\hline & Croton glandulosus & 39 & 20.83 & 17.26 & 13.92 & 52.01 \\
\hline & Paspalum multicaule & 25 & 8.33 & 11.06 & 22.30 & 41.70 \\
\hline & Croton lobatus & 12 & 12.50 & 5.31 & 7.14 & 24.95 \\
\hline & Lantana camara & 9 & 16.67 & 3.98 & 4.01 & 24.66 \\
\hline & Pueraria phaseoloides & 12 & 8.33 & 5.31 & 10.70 & 24.35 \\
\hline & Axonopus affinis & 6 & 8.33 & 2.65 & 5.35 & 16.34 \\
\hline & Total & 226 & 100.00 & 100.00 & 100.00 & 300.00 \\
\hline \multirow{4}{*}{ B. ruziziensis } & Mimosa pudica & 85 & 33.33 & 84.16 & 79.44 & 196.93 \\
\hline & Croton glandulosus & 10 & 33.33 & 9.90 & 9.35 & 52.58 \\
\hline & Croton lobatus & 3 & 16.67 & 2.97 & 5.61 & 25.24 \\
\hline & Axonopus affinis & 3 & 16.67 & 2.97 & 5.61 & 25.24 \\
\hline & Total & 101 & 100.00 & 100.00 & 100.00 & 300.00 \\
\hline \multirow{6}{*}{ M. pruriens } & Mimosa pudica & 106 & 31.58 & 72.11 & 56.38 & 160.07 \\
\hline & Paspalum multicaule & 20 & 15.79 & 13.61 & 21.28 & 50.67 \\
\hline & Croton glandulosus & 14 & 21.05 & 9.52 & 11.17 & 41.75 \\
\hline & Croton lobatus & 3 & 15.79 & 2.04 & 3.19 & 21.02 \\
\hline & Lantana camara & 3 & 10.53 & 2.04 & 4.79 & 17.35 \\
\hline & Pueraria phaseoloides & 1 & 5.26 & 0.68 & 3.19 & 9.13 \\
\hline & Total & 147 & 100.00 & 100.00 & 100.00 & 300.00 \\
\hline \multirow{6}{*}{ C. ensiformis } & Mimosa pudica & 61 & 30.77 & 67.03 & 45.86 & 143.67 \\
\hline & Croton glandulosus & 12 & 23.08 & 13.19 & 12.03 & 48.29 \\
\hline & Paspalum multicaule & 6 & 7.69 & 6.59 & 18.05 & 32.33 \\
\hline & Lantana camara & 6 & 15.38 & 6.59 & 9.02 & 31.00 \\
\hline & Croton lobatus & 4 & 7.69 & 4.40 & 12.03 & 24.12 \\
\hline & Axonopus affinis & 2 & 15.38 & 2.20 & 3.01 & 20.59 \\
\hline & Total & 91 & 100.00 & 100.00 & 100.00 & 300.00 \\
\hline
\end{tabular}

Concerning the population dynamics of the weed plants, the main differences observed were in terms of the number of species and total number of individuals, and it was not possible to identify control patterns among the weed species and the assessed treatments, with predominance of some species in most treatments, especially M. pudica, P. multicaule, and C. glandulosus.

For the total number of individuals in the second year, the cover crops with B. ruziziensis, C. ensiformis, and $M$. pruriens provided reductions of 55,60 , and $35 \%$, respectively, when compared with the treatment with no weed control. With respect to the quantity of weed species, B. ruziziensis was again the cover crop with the lowest quantity (4), which underlines its competitive ability.

The variations observed in the weed species and in the phytosociological parameters assessed in the surveys conducted at the beginning and end of this study corroborate the understanding of the floristic composition of the weed plants as a natural dynamic, fluid 
process, where agricultural practices, soil management system, and the cultural practices adopted can promote significant changes [30].

In general, the weed species identified in the present surveys were recorded in other studies and are commonly found in the Amazon region and are well adapted to the regional conditions. From this perspective, more in-depth studies on the ecology and behavior of these species with respect to different methods of control are necessary for the development of sustainable control strategies.

\subsection{Cassava Yield}

The summary of variance of the yield components of cassava intercropping with different cover crops is shown in Table 5. Regarding the weed management practice, there was significance for root fresh matter, root dry matter, and shoot dry matter, and no difference for plant height and diameter of the stem base.

Table 5. Summary of the analysis of variance of yield components of cassava culture in cassava production system with different weed management practices in 2018/2019 and 2019/2020 seasons. Manaus, AM.

\begin{tabular}{ccccccc}
\hline \multirow{2}{*}{ SV } & DF & \multicolumn{5}{c}{ Means Squares } \\
\cline { 3 - 7 } & & RFM $^{\mathbf{1}}$ & RDM & SDM & PH & SBD \\
\hline Block & 3 & $0.466^{\mathrm{ns}}$ & $0.068^{\mathrm{ns}}$ & $0.052^{\mathrm{ns}}$ & $116.8^{\mathrm{ns}}$ & $52.311^{*}$ \\
Management & 5 & $2.915^{*}$ & $0.428^{*}$ & $0.242^{*}$ & $1224.5^{\mathrm{ns}}$ & $5.660^{\mathrm{ns}}$ \\
Year & 1 & $0.075^{\mathrm{ns}}$ & $0.456^{*}$ & $0.023^{\mathrm{ns}}$ & $3316.7^{*}$ & $59.608^{*}$ \\
Man $\times$ year & 5 & $0.020^{\mathrm{ns}}$ & $0.017^{\mathrm{ns}}$ & $0.006^{\mathrm{ns}}$ & $251.1^{\mathrm{ns}}$ & $5.814^{\mathrm{ns}}$ \\
Residual & 33 & 0.180 & 0.053 & 0.020 & 536.2 & 12.561 \\
\hline Total & 47 & - & - & & - & - \\
\hline
\end{tabular}

${ }^{1}$ RFM = Root fresh matter; RDM = Root dry matter; SDM = Shoot dry matter; PH = Plant height; and SBD = Stem base diameter; ${ }^{*}=$ Significant difference; and ${ }^{\mathrm{ns}}=$ not significant at the $5 \%$ probability level, F-test.

With respect to yield, the treatment with chemical control achieved the best results $\left(29.23 \mathrm{t} \mathrm{ha}^{-1}\right)$, followed by mechanical control $\left(21.79 \mathrm{t} \mathrm{ha}^{-1}\right)$ and B. ruzizienis $\left(17.60 \mathrm{t} \mathrm{ha}^{-1}\right)$ and C. ensiformis $\left(15.47 \mathrm{t} \mathrm{ha}^{-1}\right)$ cover crops. The lowest yields were observed in the treatments with $M$. pruriens $\left(13.77 \mathrm{t} \mathrm{ha}^{-1}\right)$ and with no weed control $\left(13.60 \mathrm{t} \mathrm{ha}^{-1}\right)$ (Table 6).

Table 6. Cassava yield components in cassava production system with different management practices in 2018/2019 and 2019/2020 growing seasons. Manaus, AM.

\begin{tabular}{cccc}
\hline Treatments & RFM $^{\mathbf{1}}$ & $\begin{array}{c}\text { RDM } \\
\mathbf{t ~ h a}^{\mathbf{1}}\end{array}$ & SDM \\
\hline No weed control & $13.60 \mathrm{c}$ & $7.99 \mathrm{c}$ & $6.93 \mathrm{~b}$ \\
Mechanical control & $21.79 \mathrm{~b}$ & $11.84 \mathrm{ab}$ & $8.95 \mathrm{~b}$ \\
Chemical control & $29.23 \mathrm{a}$ & $13.60 \mathrm{a}$ & $11.51 \mathrm{a}$ \\
B. ruziziensis & $17.60 \mathrm{bc}$ & $9.78 \mathrm{bc}$ & $7.30 \mathrm{~b}$ \\
C. ensiformis & $15.47 \mathrm{bc}$ & $9.86 \mathrm{bc}$ & $7.55 \mathrm{~b}$ \\
M. pruriens & $13.77 \mathrm{c}$ & $7.48 \mathrm{c}$ & $7.30 \mathrm{~b}$ \\
\hline CV (\%) & 22.85 & 22.87 & 17.48 \\
\hline Growing season 2017/2018 & $18.97^{\mathrm{ns}}$ & $9.12 \mathrm{a}$ & $8.03^{\mathrm{ns}}$ \\
Growing season 2018/2019 & $18.18^{\mathrm{ns}}$ & $11.06 \mathrm{~b}$ & $8.48^{\mathrm{ns}}$ \\
\hline
\end{tabular}

${ }^{1}$ RFM = Root fresh matter; RDM = Root dry matter; SDM = Shoot dry matter. Means followed by same letter in column and ${ }^{\text {ns }}$ do not differ statistically from each other by the Tukey test $(p<0.05)$.

Although cassava is recognized as rustic plant, fresh root yield was severely affected by weed interference. The treatment with no weed control exhibited more than $50 \%$ yield loss compared with the treatment with chemical control, which shows the importance of weed management in cassava yield. Fontes et al. [31] studied the periods of interference of 
weeds with cassava cultivar Manteiga and found that the coexistence of the culture with weeds throughout the crop cycle reduced yields by $96 \%$. According to these authors, this cultivar has low competitive ability against weeds in Amazonas dry land.

The treatment with chemical weed control showed the highest values of yield, root dry matter and shoot dry matter values, probably due to the formation of a uniform straw bed on the soil surface after herbicide application, which may have worked as a physical barrier, helping to keep water in the soil and preventing the emergence of new weeds. The hand-hoeing weed treatment may have suffered the effects of the weed interference found in the treatment, as well as of lower water availability due to the greater soil exposure, which favors water loss to the atmosphere. Although the hoeing treatment achieved lower yields compared with the chemical control, both treatments did not show differences with respect to root dry matter.

In this regard, other studies evaluating weed control in cassava crop fields recorded higher yields in treatments with herbicide applications, compared with treatments using hand weed control [32,33]. Different results were found by Fontes et al. [17], who did not observe differences in cassava cultivar Manteiga yields with herbicide and hand weeding treatments.

With respect to the cover crops, B. ruziziensis and C. ensiformis showed a moderate degree of interference with cassava, providing yield values similar to the ones achieved with the mechanical control due to the growth habit of these plants, which is compatible with the culture, and reduced quantity of weed species, resulting in less interference when compared with the treatment with no weed control. It should be emphasized that future studies evaluating planting time, density, spacing, and adequate intercropping time, can contribute to raise cassava yields and reduce the potential of weed interference on this crop.

Mucuna pruriens did not show differences from the treatment with no weed control for any of the assessed parameters, indicating intercropping incompatibility with cassava, mainly as a function of its climbing growth habit. However, as it is a rustic legume and of rapid establishment, it has potential for use as green manure or mulch, if cultivated in an area not intercropped with cassava, or even in rotation with this culture.

According to Madembo et al. [34], although intercropped systems with cover crops may reduce crop yields, the use of these plants can be a viable alternative, especially for small farmers, being necessary to investigate crop arrangements capable of increasing the weed suppression potential and reduce interference with the culture.

Despite the importance of optimal production rates, the stability, sustainability of crops, producers' health, preservation, and maintenance of the Amazon ecosystem are factors that must be considered when choosing the best weed management system. It is worth noting that a sustainable production system, when properly employed, adds value to the end product, and can even compensate for any yield losses.

\subsection{Soil Chemical Properties}

With respect to the chemical properties of soil, despite the variations observed in the two growing seasons, higher $\mathrm{pH}, \mathrm{K}, \mathrm{Ca}, \mathrm{Mg}$, and organic matter contents were found for the cover crops compared to the chemical and mechanical control treatments (Table 7).

The favorable $\mathrm{pH}$ value for growing cassava in the North region of Brazil ranges from 5.5 to 7 , and 6.5 is the ideal $\mathrm{pH}$ [35]. The cover crops contributed to raise the $\mathrm{pH}$ value, being closer to the ideal $\mathrm{pH}$ for the culture, in comparison to the chemical and mechanical treatments. The effects of the cover crops on the soil $\mathrm{pH}$ values are still not fully understood, and contradictory findings are reported in the literature, sometimes with higher values, sometimes with lower values $[36,37]$. Such variations seem to be mainly related to the biochemical compositions of the cover crops, the soil characteristics, the environmental conditions, and the type of management used.

Regarding organic matter, the cover crops achieved higher values compared to chemical and mechanical weed controls. Higher concentrations of organic matter in soil when using cover crops have been mainly attributed to the incorporation of plant residues, the 
reduction of the mineralization rate by adopting conservative practices, and less loss of organic matter caused by erosion [38,39]. According to Oliveira et al. [40], agricultural crops that do not use conservation practices tend to reduce the contents of organic matter in soil, especially in the topsoil. Low contents of organic matter tend to diminish the availability of nutrients, such as $\mathrm{K}, \mathrm{Ca}$, and $\mathrm{Mg}$, causing more dependence on chemical fertilizers [41,42].

Table 7. Soil chemical properties in the 0 to $20 \mathrm{~cm}$ layer, in a cassava production system with different weed management practices in 2018/2019 and 2019/2020. Manaus, AM.

\begin{tabular}{|c|c|c|c|c|c|c|c|c|}
\hline \multirow{3}{*}{ Treatments } & $\mathrm{pH}^{1}$ & OM & $\mathbf{P}$ & $\mathbf{K}$ & $\mathrm{Ca}$ & Mg & $\mathrm{Zn}$ & $\mathbf{H}+\mathbf{A l}$ \\
\hline & $\mathrm{H}_{2} \mathrm{O}$ & dag/kg & \multicolumn{2}{|c|}{$\mathrm{mg} / \mathrm{dm}^{3}$} & \multicolumn{2}{|c|}{$\mathrm{cmol}_{\mathrm{c}} / \mathrm{dm}^{3}$} & $\mathrm{mg} / \mathrm{dm}^{3}$ & $\mathrm{cmol}_{\mathrm{c}} / \mathrm{dm}^{3}$ \\
\hline & \multicolumn{8}{|c|}{$2018 / 2019$} \\
\hline Mechanical control & $5.62 c$ & $3.52 c$ & $3.10 \mathrm{ab}$ & $22.75 c$ & $1.88 \mathrm{c}$ & $1.18 \mathrm{~d}$ & $0.65^{\mathrm{ns}}$ & $4.37 \mathrm{bc}$ \\
\hline No weed control & $5.82 \mathrm{~b}$ & $3.69 \mathrm{bc}$ & $3.45 \mathrm{ab}$ & $27.00 \mathrm{~b}$ & $2.25 \mathrm{~b}$ & $1.50 \mathrm{ab}$ & $0.75^{\mathrm{ns}}$ & $4.53 \mathrm{bc}$ \\
\hline B. ruziziensis & $6.20 \mathrm{a}$ & $3.86 \mathrm{ab}$ & $2.92 \mathrm{~b}$ & $35.75 \mathrm{a}$ & $2.56 \mathrm{a}$ & $1.52 \mathrm{a}$ & $0.75^{\mathrm{ns}}$ & $4.20 \mathrm{c}$ \\
\hline C. ensiformis & $5.80 \mathrm{bc}$ & $3.86 \mathrm{ab}$ & $3.97 \mathrm{ab}$ & $23.50 \mathrm{c}$ & $2.10 \mathrm{~b}$ & $1.4 \mathrm{bc}$ & $0.72^{\mathrm{ns}}$ & $4.86 \mathrm{~b}$ \\
\hline M. pruriens & $5.82 \mathrm{~b}$ & $4.06 \mathrm{a}$ & $3.27 \mathrm{ab}$ & $29.25 b$ & $2.07 \mathrm{bc}$ & $1.32 \mathrm{bc}$ & $0.75^{\mathrm{ns}}$ & $5.52 \mathrm{a}$ \\
\hline Chemical control & $5.67 \mathrm{bc}$ & $3.56 \mathrm{c}$ & $4.25 \mathrm{a}$ & $22.75 \mathrm{c}$ & $1.88 \mathrm{c}$ & $1.36 \mathrm{c}$ & $0.67^{\mathrm{ns}}$ & $4.62 \mathrm{bc}$ \\
\hline \multirow[t]{2}{*}{ CV (\%) } & 1.46 & 2.86 & 15.75 & 4.19 & 4.30 & 3.62 & 13.07 & 6.11 \\
\hline & \multicolumn{8}{|c|}{$2019 / 2020$} \\
\hline Mechanical control & $5.20 \mathrm{c}$ & $3.86 \mathrm{c}$ & $3.80 \mathrm{ab}$ & $24.25 \mathrm{~d}$ & $1.04 \mathrm{~d}$ & $0.46 \mathrm{~d}$ & $0.70 \mathrm{bc}$ & $7.34 \mathrm{a}$ \\
\hline No weed control & $5.30 \mathrm{c}$ & $4.19 \mathrm{ab}$ & $2.45 c$ & $27.50 \mathrm{c}$ & $1.19 \mathrm{c}$ & $0.47 \mathrm{c}$ & $0.72 \mathrm{bc}$ & $6.51 \mathrm{ab}$ \\
\hline B. ruziziensis & $5.50 \mathrm{~b}$ & $4.39 \mathrm{a}$ & $3.37 \mathrm{~b}$ & $30.75 \mathrm{a}$ & $1.37 \mathrm{~b}$ & $0.61 \mathrm{bc}$ & $0.95 \mathrm{a}$ & $6.60 \mathrm{ab}$ \\
\hline C. ensiformis & $5.82 \mathrm{a}$ & $4.23 \mathrm{a}$ & $3.57 \mathrm{ab}$ & $29.00 \mathrm{~b}$ & $1.56 \mathrm{a}$ & $0.69 \mathrm{a}$ & $0.60 \mathrm{c}$ & $6.43 \mathrm{~b}$ \\
\hline M. pruriens & $5.60 \mathrm{~b}$ & $4.16 \mathrm{ab}$ & $3.42 \mathrm{ab}$ & $30.50 \mathrm{a}$ & $1.18 \mathrm{c}$ & $0.64 \mathrm{~b}$ & $0.82 \mathrm{ab}$ & $7.43 \mathrm{a}$ \\
\hline Chemical control & $5.32 \mathrm{c}$ & $3.93 \mathrm{bc}$ & $4.10 \mathrm{a}$ & $24.25 \mathrm{~d}$ & $1.06 \mathrm{~d}$ & $0.47 \mathrm{~d}$ & $0.75 \mathrm{~b}$ & $6.93 \mathrm{ab}$ \\
\hline CV (\%) & 1.28 & 2.89 & 7.95 & 2.34 & 2.60 & 2.75 & 7.86 & 5.28 \\
\hline
\end{tabular}

$1 \mathrm{pH}=$ Power of hydrogen; OM = Organic matter; $\mathrm{P}=$ Phosphorus; $\mathrm{K}=$ Potassium; Ca = Calcium; $\mathrm{Mg}=$ Magnesium; $\mathrm{Zn}=$ Zinc; and $\mathrm{H}+\mathrm{Al}=$ Potential acidity. Means followed by same letter in column and ${ }^{\mathrm{ns}}$ do not differ statistically from each other by the Tukey test $(p<0.05)$.

In the first year, B. ruziziensis was the species that exhibited the highest contents of K, $\mathrm{Ca}, \mathrm{Mg}$, and organic matter and the lowest potential acidity. Because it is a species that produces great amount of biomass, with capacity to uptake nutrients from the deepest layers in soil [43], the cutting and rapid degradation of vegetable residues that this species has have contributed to the improved level of chemical properties observed in the upper layers of soil. Similar results were found by Ensinas et al. [44], who studied the effects of some cover crops on the chemical properties of soil, including B. ruziziensis, and found that the cover crops provided improved $\mathrm{K}$ and $\mathrm{Mg}$ contents. Arf et al. [45] reported that B. ruziziensis and C. ensiformis provided higher contents of $\mathrm{P}$ and $\mathrm{K}$ in the soil, and Demir and Iş1k [37], when they studied the influence of cover crops on the soil quality, observed that the cover crops provided increased $\mathrm{K}$ and $\mathrm{Mg}$ contents, when compared with the treatments with chemical and mechanical weed control.

It should be noted that $B$. ruzizienis was the cover crop that exhibited the lowest $P$ contents in the soil in the two years assessed. Studies involving brachiaria species and phosphorus availability in the soil reported that, contrary to expectations, $B$. ruziziensis reduced $P$ content in the soil, while exhibiting a higher P concentration in plant tissues [46,47].

The chemical control treatment achieved the best $P$ contents in the soil in both years of assessment. Considering that there was fertilization of soil with this nutrient, following recommendation of Dias et al. [11], it is possible that the higher P contents found in this treatment were due to the absence of weeds or cover crops capable of extracting this nutrient from the soil and better conservation of the soil surface provided by crop residues (straw). According to Magolbo [48], because it participates in the synthesis of starch in the plants, it is expected that $\mathrm{P}$ supply in adequate amounts can increase the plant growth and 
cassava yields. So, greater $\mathrm{P}$ contents in soil are highly desirable for cassava, and many studies demonstrate that this is a crop responsive to phosphate fertilization [48-50].

As for $\mathrm{Zn}$ contents, no differences were observed between the treatments in the first year, but $B$. ruziziensis and $M$. pruriens exhibited higher contents of this micronutrient in the second year. Due to the variations found, future studies are necessary to assess the real impact of these cover crops on Zn contents in soil, considering that this is an essential micronutrient for plant growth, and its deficiency in soil represents a global concern, especially in tropical soils, being considered the micronutrient that most commonly limits cassava production [51,52].

Finally, although an improvement of the chemical properties of soil is quite desirable, the mere conservation of the parameters initially observed already represents a great advance under the perspective of sustainable cropping systems, considering that conventional cultivation practices, dependent on intense use of fertilizers and pesticides, may cause degradation of the soil properties in the medium and long term.

\section{Conclusions}

Cover crops changed the floristic composition of the weed community in cassava cultivation, reducing the diversity of species and the quantity of individuals. The weed species reduced cassava yields by more than $50 \%$ under the Amazon ecosystem conditions. The cover crops B. ruziziensis and C. ensiformis increased fresh and dry matter of cassava roots when compared with the treatment with no control. The cover crops increased the $\mathrm{pH}, \mathrm{OM}, \mathrm{K}, \mathrm{Ca}$, and $\mathrm{Mg}$ when compared with the treatments with chemical and mechanical weed control.

Brachiaria ruziziensis and C. ensiformis are recommended as a cover plants in cassava production systems in the Amazon region. The use of cover crops associated with cassava is a sustainable management option because, in addition to the suppressive effect on weeds, cover crops improve the chemical properties of soil, which may contribute to increasing cassava production in the long term, considering the low natural fertility of the Amazonian soils. Although studies on this theme are still incipient in the Amazon region, the results obtained in this study are useful in the development of strategies for sustainable weed management and improvement of the quality of Amazonian soils.

Author Contributions: Conceptualization, D.O.S. and S.M.A.; methodology, D.O.S., K.G.P. and S.M.A.; software, D.O.S. and S.M.A.; validation, D.O.S., S.M.A. and P.C.B.; formal analysis, D.O.S. and S.M.A.; investigation, D.O.S.; K.G.P. and S.M.A.; resources, D.O.S., K.G.P. and S.M.A.; writingoriginal draft preparation, D.O.S.; writing-review and editing, S.M.A. and P.C.B.; supervision, S.M.A. and P.C.B.; project administration, S.M.A. and P.C.B.; funding acquisition, S.M.A. All authors have read and agreed to the published version of the manuscript.

Funding: This research was funded by the Ministério da Ciência, Tecnologia e Inovações (MCTI), Public Notice 041/2016 - PROPESP/UFAM and published with the financed support of the Fundação de Amparo e Pesquisa do Estado do Amazonas, Res. 006/2020, POSGRAD/FAPEAM.

Institutional Review Board Statement: Not applicable.

Informed Consent Statement: Not applicable.

Data Availability Statement: The data used for this research were presented in Tables 5 and 6, Section 3.2, and Table 7, Section 3.3.

Acknowledgments: The authors are grateful to the Ph.D scholarship awarded to Daniel Oscar P. Soares by the Coordenação de Aperfeiçoamento de Pessoal de Nivel Superior (CAPES sandwich mode PSDE, no. 88881.189364/2018-01), and to the Tropical Agronomy Graduate Program of the Federal University of Amazonas (PPGATR/UFAM).

Conflicts of Interest: The authors declare no conflict of interest. 


\section{References}

1. Rocha, V.P.C.; Gonçalves-Vidigal, M.C.; Ortiz, A.H.T.; Valentini, G.; Ferreira, R.C.U.; Gonçalves, T.M.; Lacanallo, G.F.; Vidigal Filho, P.S. Population structure and genetic diversity in sweet cassava accessions in Paraná and Santa Catarina, Brazil. Plant Mol. Biol. Report. 2020, 38, 25-38. [CrossRef]

2. IBGE. Instituto Brasileiro de Geografia e Estatistica. Levantamento Sistemático da Produção Agrícola—LSPA. 2020. Available online: https://www.ibge.gov.br (accessed on 10 August 2021).

3. Soares, D.O.P.; Pinto, K.G.D.; da Gama, L.A.; Ferreira, C.C.; Bhowmik, P.C.; Albertino, S.M.F. Physical Properties of Soil and Glyphosate Residue as a Function of Cassava Weed Management by Cover Crops in the Amazon Ecosystem. HortScience 2021, 56, 1053-1058. [CrossRef]

4. Hasanuzzaman, M.; Mohsin, S.M.; Bhuyan, M.B.; Bhuiyan, T.F.; Anee, T.I.; Masud, A.A.C.; Nahar, K. Phytotoxicity, environmental and health hazards of herbicides: Challenges and ways forward. In Agrochemicals Detection, Treatment and Remediation; Elsevier: Amsterdam, The Netherlands, 2020; pp. 55-99.

5. Büchi, L.; Wendling, M.; Amossé, C.; Necpalova, M.; Charles, R. Importance of cover crops in alleviating negative effects of reduced soil tillage and promoting soil fertility in a winter wheat cropping system. Agric. Ecosyst. Environ. 2018, 256, 92-104. [CrossRef]

6. Gómez, J.A.; Campos, M.; Guzmán, G.; Castillo-Llanque, F.; Vanwalleghem, T.; Lora, Á.; Giraldez, J.V. Soil erosion control, plant diversity, and arthropod communities under heterogeneous cover crops in an olive orchard. Environ. Sci. Pollut. Res. 2018, 25, 977-989. [CrossRef] [PubMed]

7. Michelon, C.J.; Junges, E.; Casali, C.A.; Pellegrini, J.B.R.; Neto, L.R.; de Oliveira, Z.B.; de Oliveira, M.B. Atributos do solo e produtividade do milho cultivado em sucessão a plantas de cobertura de inverno. Rev. Ciências Agroveterinárias 2019, 18, 230-239. [CrossRef]

8. Soares, M.R.S.; São José, A.R.; Nunes, R.T.C.; de Andrade Silva, R.; Caetano, A.P.O.; de Oliveira, D.S.; de Azevedo Nolasco, C.; Rampazzo, M.C. Períodos de interferência de plantas infestantes na cultura da mandioca, submetida ou não à adubação NPK, em Vitória da Conquista-Ba. Rev. Ciências Agrárias 2019, 42, 237-247.

9. Dubreuil, V.; Fante, K.P.; Planchon, O.; Neto, J.L.S. Os tipos de climas anuais no Brasil: Uma aplicação da classificação de Köppen de 1961 a 2015. Confins. Rev. Fr.-Brésilienne Géographie/Rev. Fr.-Bras. Geogr. 2018, 72. [CrossRef]

10. Vieira, A.F.S.G.; Junior, J.C.M.D. Padrões pluviométricos da Cidade de Manaus-AM: 1986 a 2015. Bol. Paul. Geogr. $2020,1,1-31$.

11. Dias, M.C.; Xavier, J.; Barreto, J.; Pamplona, A. Recomendações técnicas do cultivo de mandioca para o Amazonas. Embrapa Amaz. Ocident.-Circ. Técnica (INFOTECA-E) 2004, 1, 1-24.

12. De Oliveira, I.J.; Barreto, J.F. Épocas de colheita da macaxeira cultivar Aipim Manteiga em Latossolo Amarelo no estado do Amazonas. Embrapa Amaz. Ocident.-Circ. Técnica (INFOTECA-E) 2020, 77, 1-12.

13. Mueller-Dombois, D.; Ellenberg, H. Aims and Methods of Vegetation Ecology; John Wiley: New York, NY, USA, 1974.

14. Pinheiro, W.L.; da Silva Maia, G.; de Almeida, F.; de Cristo Silva, R.R.; Cruz, J.D.; de Souza, R.M. Características agronômicas e produção da mandioca (Manihot esculenta Crantz cv. BRS-Poti) submetida a tratos culturais. Braz. J. Dev. 2021, 7, 18314-18325. [CrossRef]

15. Raij, B.v.; Quaggio, J. Métodos de análise de solo para fins de fertilidade. Bol. Técnico IAC 1983, 81, 1-31.

16. RStudio Team. RStudio: Integrated Development Environment for R; RStudio: Boston, MA, USA, 2020. Available online: https: //www.rstudio.com (accessed on 7 August 2021).

17. Fontes, J.R.A.; Oliveira, I.J.; Morais, R.R. Selectivity and efficiency of herbicides in cassava on the floodplain of the Solimões river. Rev.Agro@ Mbiente-Line 2021, 15. [CrossRef]

18. Da Gama, L.A.; Leite, B.N.; Pinheiro, S.C.; Reis, M.F.; Pinto, K.G.D.; Soares, D.O.P.; do Nascimento Filho, F.J.; Albertino, S.M.F. Phytosociology and cover analysis in the suppression of weeds from an Amazonian agrosystem. Rev. Bras. Ciências Agrárias 2020, 15, 1-9. [CrossRef]

19. Damasceno, L.A. Produtividade do Milho em Sucessão a Plantas de Cobertura de Solo. Ph.D. Thesis, Tropical Agronomy of the Federal University of Amazonas, Manaus, Brazil, 2019.

20. De Almeida, U.O.; Andrade Neto, R.D.C.; Marinho, J.D.S.; Gomes, R.R.; de Oliveira, J.R.; dos Santos, R.S.; Teixeira Júnior, D.; de Araújo, J.C. Fitossociologia de plantas daninhas em cultivo de açaizeiro. Embrapa Acre-Artig. Em Periódico Indexado (ALICE) 2019, 9, 59-67. [CrossRef]

21. Santos, A.F.D. Controle de Plantas Daninhas na Cultura do Guaranazeiro com Herbicidas, e Seus Efeitos Sobre Bioindicadores. Ph.D. Thesis, Tropical Agronomy of the Federal University of Amazonas, Manaus, Brazil, 2018.

22. Miléo, L.; Silva, J.; Albertino, S.; Leite, B.; Menezes, D.; Santos, A. Phytosociology of weeds in cultivation of two varieties of cassava1. Planta Daninha 2016, 34, 267-276. [CrossRef]

23. Albertino, S.; Silva, J.; Parente, R.; Souza, L. Composição florística das plantas daninhas na cultura de guaraná (Paullinia cupana), no estado do Amazonas. Planta Daninha 2004, 22, 351-358. [CrossRef]

24. Pinheiro, C.; Rosa, L.; Falqueto, A. Resilience in the functional responses of Axonopus affinis Chase (Poaceae) to diurnal light variation in an overgrazed grassland. Agric. For. Meteorol. 2019, 266, 140-147. [CrossRef]

25. Silva-López, R.E.D. Canavalia ensiformis (L.) DC (Fabaceae). Rev. Fitos 2012, 7, 146-154.

26. Lorenzi, H. Plantas Daninhas do Brasil: Terrestres, Aquáticas, Parasitas e Tóxicas, 4th ed.; Plantarum: Viçosa, Brazil, 2008. 
27. Chauhan, B.S.; Johnson, D.E. Germination, emergence, and dormancy of Mimosa pudica. Weed Biol. Manag. $2009,9,38-45$. [CrossRef]

28. Alves Albuquerque, J.d.A.; Santos, T.S.d.; Castro, T.S.; Evangelista, M.O.; Arcanjo Alves, J.M.; Soares, M.B.B.; de Menezes, P.H.S. Estudo florístico de plantas daninhas em cultivos de melancia na Savana de Roraima, Brasil. Sci. Agropecu. 2017, 8, 91-98. [CrossRef]

29. de Oliveira, O.M.S. Capacidade Competitiva de Cultivares de Feijão-Caupi (Vigna unguiculata (L.) Walp) Combinada com Espaçamento na Supressão de Plantas Daninhas. Ph.D. Thesis, Tropical Agronomy of the Federal University of Amazonas, Manaus, Brazil, 2014.

30. Oliveira, A.; Freitas, S.D.P. Levantamento fitossociológico de plantas daninhas em áreas de produção de cana-de-açúcar. Planta Daninha 2008, 26, 33-46. [CrossRef]

31. Fontes, J.; de Oliveira, I.; Pedrozo, C.; da Rocha, R.; de Morais, R.; Muniz, A. Períodos de interferência de plantas daninhas na cultura da macaxeira, variedade Aipim-Manteiga, em terra firme do Amazonas. Embrapa Amaz. Ocident.-Circ. Técnica (INFOTECA-E) 2014, 46, 1-8.

32. AUgbe, L.; Nyong, J.-F.; Akomaye, U.E. A comparative analysis of the efficacies of six selected herbicides for effective control of spear grass (Imperata cylindrical Linn) in cassava production in Obudu, Northern Cross River State. GSC Biol. Pharm. Sci. 2021, 15, 272-280. [CrossRef]

33. Ekeleme, F.; Dixon, A.; Atser, G.; Hauser, S.; Chikoye, D.; Korie, S.; Olojede, A.; Agada, M.; Olorunmaiye, P.M. Increasing cassava root yield on farmers' fields in Nigeria through appropriate weed management. Crop Prot. 2021, 150, 105810. [CrossRef] [PubMed]

34. Madembo, C.; Mhlanga, B.; Thierfelder, C. Productivity or stability? Exploring maize-legume intercropping strategies for smallholder Conservation Agriculture farmers in Zimbabwe. Agric. Syst. 2020, 185, 102921. [CrossRef]

35. Mattos, P.D.; Cardoso, E. Cultivo da Mandioca Para o Estado do Pará. Cruz Almas Embrapa Mandioca Frutic (Eletronic Version). Available online: https: / sistemasdeproducao.cnptia.embrapa.br (accessed on 15 December 2021).

36. Abdollahi, L.; Munkholm, L.J. Tillage system and cover crop effects on soil quality: I. Chemical, mechanical, and biological properties. Soil Sci. Soc. Am. J. 2014, 78, 262-270. [CrossRef]

37. Demir, Z.; Issık, D. Using cover crops to improve soil quality and hazelnut yield. Fresenius Environ. Bull. 2020, 29, 1974-1987.

38. Alvarez, R.; Diaz, R.A.; Barbero, N.; Santanatoglia, O.J.; Blotta, L. Soil organic carbon, microbial biomass and $\mathrm{CO}_{2}-\mathrm{C}$ production from three tillage systems. Soil Tillage Res. 1995, 33, 17-28. [CrossRef]

39. Novara, A.; Minacapilli, M.; Santoro, A.; Rodrigo-Comino, J.; Carrubba, A.; Sarno, M.; Venezia, G.; Gristina, L. Real cover crops contribution to soil organic carbon sequestration in sloping vineyard. Sci. Total Environ. 2019, 652, 300-306. [CrossRef]

40. Oliveira, F.C.C.; Pedrotti, A.; Felix, A.G.S.; Souza, J.L.S.; Holanda, F.S.R.; Junio, A.V.M. Características químicas de um Argissolo e a produção de milho verde nos Tabuleiros Costeiros sergipanos. Rev. Bras. Ciências Agrárias 2017, 12, 354-360. [CrossRef]

41. Chiodini, B.M.; da Silva, A.G.; Negreiros, A.B.; Magalhães, L.B. Matéria orgânica e a sua influência na nutrição de plantas. Rev. Cultiv. Saber 2013, 6, 181-190.

42. Noor, R.; Wang, Z.; Umair, M.; Ameen, M.; Misaal, M.; Sun, Y. Long-term application effects of organic and chemical fertilizers on soil health and productivity of taramira (Eruca sativa L.) Under rainfed conditions. J. Anim. Plant Sci. 2020, 30, 970-987.

43. Oliveira, P.D.; Kluthcouski, J.; Borghi, E.; Ceccon, G.; Castro, G. Atributos da braquiária como condicionador de solos sob integração lavoura-pecuária e integração lavoura-pecuária-floresta. Embrapa Arroz Feijão-Col Criar Plantar ABC 500p/500r Saber (INFOTECA-E) 2015, 1, 333-353.

44. Ensinas, S.C.; Serra, A.P.; Marchetti, M.E.; da Silva, E.F.; Lourente, E.R.P.; do Prado, E.A.F.; Matos, F.A.; Altomar, P.H.; Martinez, M.A.; Potrich, D.C. Cover crops affect the soil chemical properties under no-till system. Aust. J. Crop Sci. 2016, 10, 1104-1111. [CrossRef]

45. Arf, O.; Meirelles, F.; Portugal, J.; Buzetti, S.; de Sá, M.; Rodrigues, R. Benefits of intercropping corn with grassy and legumes and their effects on yield in no tillage system. Rev. Bras. Milho E Sorgo 2018, 17, 431-444. [CrossRef]

46. Janegitz, M.C.; Martins, A.R.H.; Rosolem, C.A. Cover crops and soil phosphorus availability. Commun. Soil Sci. Plant Anal. 2017, 48, 1240-1246. [CrossRef]

47. Almeida, D.S. Disponibilidade de Fósforo e Produtividade de Soja em Rotação com Braquiária Ruziziensis. Ph.D. Thesis, Agronomy. Universidade Estadual Paulista, Botucatu, Brazil, 2018.

48. Magolbo, L.A.D.S. Efeito da Adubação Fosfatada no Crescimento, Produtividade e Acúmulo de Fósforo e Amido em Mandioca Para Indústria. Masters Dissertation, Agronomic Science of the Universidade Estadual Paulista, Botucatu, Brazil, 2019.

49. De Lima, A.G.; de Carvalho, L.R.; Mota, M.C.; de Lima Junior, A.F.; Moreira, J.M.; da Silva, A.P.; Barbuio, R.; Rosa, J.Q.S. Produtividade de mandioca avaliada sobre adubação fosfatada e a adubação de cobertura. Pubvet 2018, 12, 133.

50. Uchôa, S.; Alves, J.; Melo, V.; Silva, D.C.O.; Silva, A.; Batista, K.; Matos, K.; Albuquerque, J. Adubação fosfatada na produtividade e qualidade de raízes tuberosas de cultivares de mandioca na savana amazônica, Brasil. Rev. Ciências Agrárias 2020, 43, 381-389.

51. Brancaliao, S.R.; Campos, M.; Bicudo, S. Crescimento e desenvolvimento de plantas de mandioca em função da calagem e adubação com zinco. Nucleus 2015, 12, 175-182.

52. de Morais, E.G.; Silva, C.A.; Jindo, K. Humic Acid Improves Zn Fertilization in Oxisols Successively Cultivated with MaizeBrachiaria. Molecules 2021, 26, 4588. [CrossRef] [PubMed] 